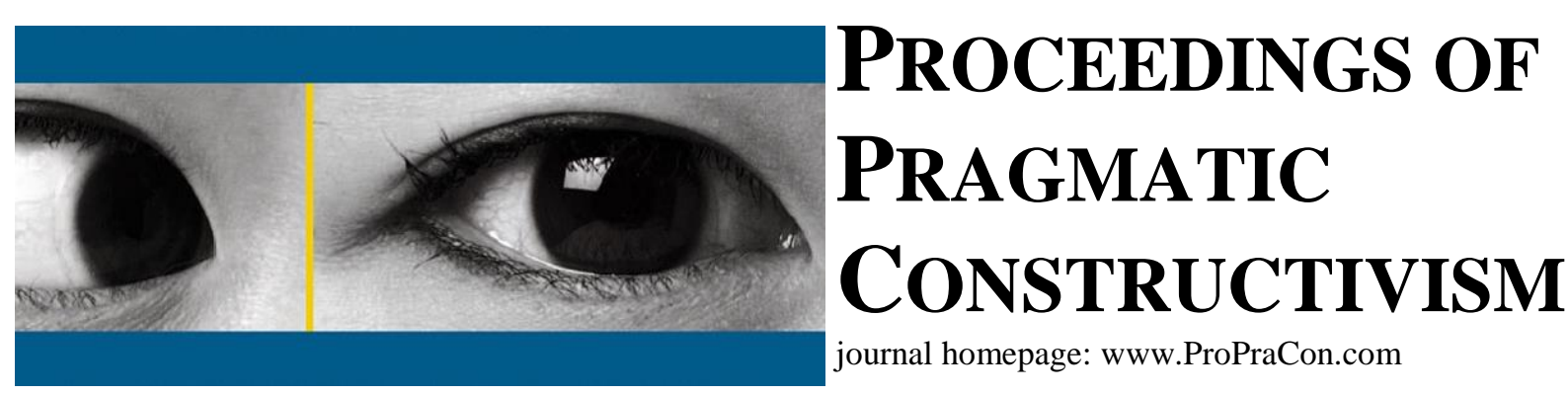

\title{
Understanding the Anthropocene world - contemporary difficulties
}

\author{
Michael Paulsen \\ University of Southern Denmark \\ Email: mpaulsen@sdu.dk
}

\begin{abstract}
It is proposed that we need to develop a new educational language game that is responsive to both a) our understanding of the world and b) the world in itself, but also responsive to c) the fact that we now live in an Anthropocene world, and that this d) calls for a shift in both our world understanding and our view on education. Very broadly speaking this can be understood as a demand for a shift in what education should be about. In the Late Holocene humans fostered education as an enterprise that worked with helping new generations with changing themselves for the (presumed) better. Yet the educational aim was tied to the Holocene world view, and also its possibility of being actualized was conditioned by the life conditions of the Holocene world. When we today witness a shift in world view and world conditions, it is argued that it calls for an adjustment of what education should be about and how it should proceed. If we keep on with Holocene education - through families, schools, companies, art etc. - it implies that we try to keep on helping new generations to change themselves to function in a world that no longer exists and tie them to a worldview that is highly problematic, reductive and destructive.
\end{abstract}

Keywords: Double shift, World, Understanding, Anthropocene, Language game, Realism, Idealism, Education

\section{Introduction}

In this paper I propose that we need to develop a "double-sided language" based on a distinction between a) the world as it is and b) how we understand the world we live in. ${ }^{1}$

On the one hand Kant, German idealism and many philosophers since then - including the linguistic turn and the late Wittgenstein's idea of language games - argue (explicit or implicit) that we human beings have no direct access to the world as it is. We only have access to how we understand, speak about and "play" the world - i.e. through our reality construction we structure our world. Following this line of thought, researchers within social sciences and humanities tend to make analysis of only human language, culture, text, signification, understanding, meaning etc.

On the other hand, new philosophical movements like new materialism (e.g. Bennet, 2010; Bryant, 2014), speculative realism (e.g. Harman, 2018; Morton, 2018) and posthumanism (e.g. Braidotti, 2013; Haraway, 2016) argue that we should pay more heed to the fact that we human beings are embedded in a world together with non-humans. From this point of view and in light of global warming etc. it is important to also understand how the world (as it is) functions, structures our life and how "it is to be" for other agents than only humans. ${ }^{2}$ Further they argue that it is actually possible to make non-perfect interferences about how the world functions and how other agencies than humans relate to the world. Following this line of thought one should pay more heed to material entities, how the world appears

\footnotetext{
${ }^{1}$ Similar to the distinction made by Nørreklit (2017) between world and reality.

${ }^{2}$ Cf. Bogost (2012) and his concept alien phenomenology.
} 
for non-humans, and how our human activities are mixed with and structured by and also violating different "more than human" entities and relationships.

The purpose of the paper is to argue that we need to combine the two perspectives, paying attention to both our human world understanding and the more than human world - and thus the interplay between the two - what I call the double entanglement. I will start with general thoughts about this, but end with focusing on the educational implications, arguing that we today need to develop a new educational language game (than the one developed throughout human history). ${ }^{3}$

Further I will argue that the shift from "the linguistic turn" to the "material turn" reflects a shift in both our world understanding and the world as it is; a shift from the Late Holocene to the Early Anthropocene. The core of my argument is, that only by working out a double-sided-language that embrace the complementarity of the world as we humans relate to it and the world itself including how other entities relate to the world it will be possible to educate our self to adequately cope with the "Anthropocene problems” we face today (climate crisis, biodiversity crisis etc.). In the following I call for a double-sided language game "an anthropocene perspective”.

\section{An anthropocene perspective on the world}

The central distinction is between the Holocene and the Anthropocene.

The Holocene signifies first of all a particularly climatically stable period, beginning (as far as we know) about 11,500 years ago, when humanity began to spread to the entire earth. At the end of the Holocene period, which we can call the Late Holocene, extending from antiquity to the present day, all the development of agriculture, the establishment of cities, the invention of written language, advanced technologies, philosophy, education and also educational thinking took place. In other words: Late Holocene is identical with historical time and civilization. It is during this period that all ideas of "humanity", education etc. have been fostered.

I use the geological term 'the late Holocene' because I want to point out that it is not only a period characterized by thinking and the development of certain relationships between human beings (often called society and culture), but also a period when humans and non-humans have become increasingly intertwined. Despite this, much thinking and practice that humans developed in the Late Holocene has been perceived as having to do only with the human world alone, while everything else has increasingly been seen as a stage and resource for human expression.

The term 'the Anthropocene', on the other hand, denotes a period that gradually arises, overlaps with and replaces the Holocene, and denotes the time in which we now live. Characteristic of this period is that human activities globally affect all other processes in the life-critical zone slightly above and slightly below the earth's surface $\neg-$ geological processes, biological processes, atmospheric processes, etc. Also, it is a period characterized by unstable climate. The early Anthropocene in which we live today is thus characterized by a high global entanglement of both humans and humans and humans and non-humans. Yet, this does not imply that human beings control or acknowledge this double entanglement. Global warming, mass extinction, decreasing biodiversity and other related phenomena indicate the opposite; that we humans neither control, nor understand the double entanglement, we are part of, today. We do not understand that our language games have two sides (because in the Holocene, we have developed most of our language games one-sided, that is without acknowledging that our life form are imbedded in a larger vital and active life-world, that is not only our life-world).

However, the case is even more complicated. The Anthropocene does not only signify that we are in a different world today, with different conditions than, say, 2500 years ago, but also that we today begin to understand ourselves and the world differently; in an anthropocene way. To understand these two aspects, I want to endorse two ideas that are often understood as contradictions, but which I believe need to be brought together in order to develop language games

\footnotetext{
${ }^{3}$ I use Wittgenstein's (1974) concept of language game as a tool to make clear that all human activities, including educational activities, are shaped by the use of language (understood very broadly) and that the use of language is always embedded in more or less concrete practical activities. These activities are according to Wittgenstein further embedded in life forms. Part of my argument in this paper is implicitly that we have to take more account of this last proposal - that all language games are embedded in life forms. If we acknowledge that human lifeforms are today - as I will argue in the paper - deeply intertwined with non-human life-forms, it implies that our language games should be thought as taken place in a collectively shared life zone slightly above and below the surface of the Earth, also accessed by all other life entities, playing roles in shaping the games and plays. As far as I know, it is more common to mainly or only address the human/cultural aspects of language games and lifeforms, when applying Wittgenstein's concept of language games, but as I try to show in the paper, this is deeply problematic.
} 
that reflect the new anthropocene situation (and thus the two-sided nature of our language games). With inspiration from Bohr, one could call it an anthropocene complementary model that seeks to bridge realism and idealism. The two thoughts are:

1) On the one hand, the realistic position, which argues that there is a world that exists and operates independently of how we understand and exist in it. After all, if you are hit by a car in traffic, it is not your traffic understanding that you are hit by, but the car itself. And thus, there are almost infinitely many processes (atmospheric, climatic, bacterial, species interactions, etc.) that in some form already have to function and work for us to exist as living, playing and understanding creatures - as conditions enabling and structuring our doings, including our thoughts about these processes. It is this realism, recent philosophical currents such as speculative realism and new materialism assert in their criticism of 2).

2) On the other hand, the idealistic position, which argues that we humans never have direct access to the world in itself. In short, this is the insight Kant and later large parts of late modern philosophy advocate for. That this should be the case is explained by the fact that man's understanding of the world in the strict sense is historical, which means that our understanding is always already structured by the historically delivered vocabulary and practices that gives us a grasp of the world, as well as emphasizing that it is not possible for man to develop practices, understanding and vocabulary of the world beyond history (culture, our way of accessing the world etc.).

As one can see, the two thoughts clash, as the realistic position claims that there is a world/Being prior to thinking, while the idealistic position claims that no world/Being would be open (and thus be) without the historically transmitted thinking about the world/Being.

However, it will be my point that we need to avoid it becoming an either-or-but-a-both, because we must consider both (1) and (2) in order to understand and navigate in the Anthropocene. On the one hand, it makes a difference what world understanding (idealism) we understand with - because every time we talk about or do something in the world (including talk about the world as such), it is based on a world understanding that we generally take for granted. On the other hand, we have not invented our world understanding in a vacuum, but rather acquired it through growing up in a world where the wind blows and the birds fly, while our hearts pump blood in our bodies. The enigmatic thing is that it is actually the wind, the birds and the heart that we understand when we understand. But at the same time, we can also understand these differently; not just because we are smart individuals or can be wrong, but first and foremost because the world can show itself differently; and when it appears in one way, it hides that it could also appear differently. For instance: If a pig shows itself as food (when we breed, consume and eat it for that reason) it cannot (in the strong sense and totally) at the same time show itself as our friend - it would at least to some degree be contradictory to simultaneously eat the pig and relate to it as a friend. Thus, the point is, that the pig itself can both be food and a friend, but to some degree not simultaneously. Neither of these possibilities are invented by us, only grasped and actualized (through understanding that reaches out). ${ }^{4}$

If we take these matters seriously, it suggests that we must develop a double-sided responsive language in which we, on the one hand, take account of ourselves, our understanding and accept the historicity of our language, but on the other hand also listen to what exists (that is to the pluripotent world itself and how it can be to others) and do what we can to give it space in our language games. Or, to put it another way: It will always be historically structured what we understand by a pig, a tree, a weather phenomenon, but at the same time we must do what we can to say/understand/reaching out to what is, as it is, and not just as we now find, we could talk about it or relate to it. This is the complementary task that Anthropocene time demands of us. Or, to put it schematically, it is true that the conditional world can only be recognized and understood through our world understanding; but our world understanding, in turn, can only arise in a world that conditions/enables it. In this way, the world is ontologically primary, while our understanding is epistemologically primary, and it is important to deal with this relationship wisely.

\section{Two examples}

Let us take two examples that illustrate the importance of considering both world in itself and our world understanding, but also show how complicated the matter is.

First example. Agriculture. The invention and propagation of agriculture in the Holocene can be said to be based on a scenic and humanistic world understanding, which is expressed not only in agriculture's growing perception of animals, plants and soil as merely resources for man, but also in the Holocene agricultural religions that legitimize

4 This concept of understanding is derived from Heidegger (2002), Caputo (2013) and Caputo (2018). 
human supremacy and are different from the animistic religions that characterized human life in the pre-Holocene. ${ }^{5}$ Very symptomatic, therefore, there is also only one example of explicit dialogue between humans and animals in the Old Testament, namely, between Eve and the serpent, which symptomatically views the serpent as a villain and leads to man being thrown out of the Garden of Eden, which has the character of a pre-Holocene world where animals and humans can talk together, and into an agricultural community where animals, plants, etc. in the rest of the Old Testament are considered human resources without intrinsic value. ${ }^{6}$ In all this lies a world understanding of a particular kind, which at the same time stimulate man to relate to the world in certain ways - ways which, one might argue, have contributed to the current state of the earth (and could be called Holocene language games).

Second example. Extinction of Mammoths. Compared to this, one might think that man's animistic doings in the pre-Holocene was much more innocent, because we were here in a completely different relation to nature. It's not that simple, though. Although the world understanding in the pre-Holocene was animistic, man as a hunter-gatherer also interfered negatively and destructively in life on earth, but probably without knowing or wishing to do so. Thus, for example, human in the pre-Holocene was the reason for the extinction of large parts of the megafauna, including all human species other than homo sapiens. It could well be said that this had to do with how humans in the pre-Holocene understood the world, insofar as it was based on lack of recognition, insight and overview. But when species and habitats were exterminated in the pre-Holocene, it was not because man only perceived everything as a resource, and the world as a scene, because, as said before, they had (presumably) an animistic worldview in which everything was perceived as connected and sacred. Instead, it was due to a combination of ignorance and processes that worked independently of man. An example: In the pre-Holocene, humans started hunting rabbits as well as mammoths (that is they developed pre-Holocene hunting language games). They did this in a deep respect for the animals and without looking down on them or simply perceiving them as resources. They probably didn't eat quite a lot of mammoths either. However, mammoths were exterminated because, unlike rabbits, they do not reproduce as rabbits. It therefore follows that it is at least not only the world understanding that matters, but also how the world actually works - and both these aspects have to be taking into to account to understand how a language game actually function. Similarly, in the Holocene. Here, the new world understanding (where everything is considered resources, especially domesticated plants, animals, and landscapes) probably involves an accelerating destruction of the Earth's life, but this is not only because of human understanding of the world, but also because parts of the world (e.g. animals, plants, soil, etc.) can actually be domesticated, exploited and destroyed. In a certain way the Holocene language games are therefore lifedestructive because they work, that is because understanding reaches out to a world that actually shows how it can be "played as being a bundle of resources" - at least in the short run, but then partly concealing that it can also be otherwise - as long as this understanding works.

\section{A double shift and a new educational raison}

With these thoughts in mind, I can now formulate what I mean by an anthropocene perspective — and thus as an idea of a double-sided responsive language game, responsive to both how we understand the world through our world understanding and responsive to the world in itself and how other entities access and depend on the world differently.

What I will argue is that today we are witnessing a shift in both world understanding and the world that conditions and enables our understanding of being-in-the-world (because our Holocene world understanding has led to problems in the world itself that shows now the deficits of this Holocene world understanding and its "workability" and we begin to realize then that the world can also be related to differently and thus being different than mere resources). We thus witness both a shift from a Holocene to an Anthropocene worldview and a shift from holocene to anthropocene living conditions. The shift is complex and not necessarily homogeneous or synchronous, but I will nevertheless propose that we are living in such a shift today.

This shift, I propose, forces us to reconsider and change the way we humans are in the world. Very broadly speaking this can be understood as a demand for a shift in what education should be about. In the Late Holocene we fostered education as an institutionalized enterprise that worked with helping new generations with changing themselves for the better (whatever that meant). Yet the educational ideal was tied to the Holocene world view, and also its possibility of being actualized was conditioned by the life conditions of the Holocene world. When we today witness a shift in both world view and world conditions, we therefore also are strongly motivated to adjust our idea of education and its aim. If we keep on with Holocene education - in families, schools, companies, novels, films etc. - it implies that we try to keep on helping new generation to change themselves to function in a world that does not any longer exist and

\footnotetext{
${ }^{5}$ Cf. Morton (2018)

${ }^{6}$ Cf. Harari (2018).
} 
tie them to a worldview that is highly problematic, reductive and destructive. Therefore, it can be predicted that educational language games and educational ideals will change in the Anthropocene; if not: we are doomed. And the most ironic thing is that it seems today first of all to be the new young generations that realize this most adequately, like Greta Thunberg and others.

However, this does not say much about what exactly characterize the world understanding and the world conditions in the late Holocene and the beginning Anthropocene, respectively. In table 1 I have tried to outline some rudimentary answers to this. Yet, it is out of the scope of this paper to explicate these indications and proposals. ${ }^{7}$ The aim here is only to indicate the possible contours of a shift, being aware that things are extremely more complex and diverse.

\begin{tabular}{|c|c|}
\hline $\begin{array}{l}\text { Characteristics of the Late Holocene } \\
\text { language game }\end{array}$ & $\begin{array}{l}\text { Characteristics of the Early Anthropocene } \\
\text { language game }\end{array}$ \\
\hline $\begin{array}{l}\text { A Late Holocene world understanding } \\
\text { Scenic and humanistic } \\
\text { Beings: resources } \\
\text { The world: a scene for human action } \\
\uparrow \downarrow\end{array}$ & $\begin{array}{l}\text { Early Anthropocene world understanding } \\
\text { Dialogical and zoological } \\
\text { Beings: you’s } \\
\text { World: coexistence } \\
\uparrow \downarrow\end{array}$ \\
\hline $\begin{array}{l}\text { Late Holocene world (conditions) } \\
\text { Infinitely large, full of resources, domestication } \\
\text { opportunities, new areas that can be cultivated and } \\
\text { climatically stable period } \\
\text { Increasing mix of humans and non-humans and } \\
\text { humans and humans }\end{array}$ & $\begin{array}{l}\text { Early Anthropocene world (conditions) } \\
\text { Too small a planet in terms of human consumption } \\
\text { level, life is under pressure, many resources are } \\
\text { running out, global warming, biodiversity crisis and } \\
\text { climatic unstable period } \\
\text { High global mix of humans and non-humans and } \\
\text { humans and humans }\end{array}$ \\
\hline $\begin{array}{l}\text { Educational ideal in the Late Holocene } \\
\text { Helping people to distance themselves from the } \\
\text { world (reflexivity/emancipation) and to be able to } \\
\text { master themselves and their reality in order to elevate } \\
\text { humanity and improve the lives of humanity }\end{array}$ & $\begin{array}{l}\text { Educational Ideal in the Anthropocene } \\
\text { Bringing humans into dialogic relationships with } \\
\text { other creatures in the life-critical zone and being able } \\
\text { to co-exist fruitfully, in order to contribute to a } \\
\text { common good life for all }\end{array}$ \\
\hline
\end{tabular}

Tab. 1. The shift from Holocene to Anthropocene language games

Basically, my thesis is that the educational language game in the Late Holocene was based on a scenic and humanistic worldview, while an anthropocene worldview is more dialogical and zoological and therefore also proposes a different educational ideal. The point, however, is not that the two world understandings and ways of thinking are radically different. Or, they are in a sense, but my point here is only two-fold: on the one hand I suggest that we have to base educational thinking and practice - and thus how we want to change ourselves and new generations to the better and what "this better" means - on a reflection on our world understanding and how the world is in itself (deduced through this understanding); on the other hand we must also reflect the shift from Late Holocene to the Anthropocene, and again not only with regards to a shift in worldview or world conditions, but both.

The upshot is that we need to develop a new educational double-sided language game responsive to both a) our understanding of the world and b) the world in itself (that is the ways things are in themselves and how they are for different entities of the world), but also responsive to c) the fact that our world is not any longer the Holocene, but the Anthropocene and this d) calls for shift in our world understanding and what education should be about (who we need/want to become).

\footnotetext{
${ }^{7}$ In Paulsen 2020 such explications can be found.
} 


\section{References}

Bennet, J. (2010). Vibrant Matter. Duke University Press.

Bogost, I. (2012). Alien Phenomenology, or what it's like to be a thing. University of Minnesota Pres.

Braidotti, R. (2013). The posthuman. Polity Press.

Bryant, L. (2014). Onto-Cartography - an ontology of machines and media. Edinburgh University Press.

Caputo, J. (2013). Truth. Penguin Books.

Caputo, J. (2018). Hermeneutics. Penguin Books.

Harari, Y. N. (2016). Homo Deus: A Brief History of Tomorrow. Vintage.

Haraway, D. (2016). Staying with the trouble. Duke University Press.

Harman, G. (2018). Speculative realism. Polity Press.

Heidegger, M. (2002). The essence of truth. Continuum.

Morton, T. (2018). Being ecological. Penguin Books.

Nørreklit, L. (2017). Actor-reality construction. In H. Nørreklit (Ed.) A philosophy of management accounting: a pragmatic constructivist approach (p. 23-71). Routledge.

Paulsen, M. (2020). From Late Holocene to early Anthropocene Educational thinking. Forthcoming.

Wittgenstein, L. (1974). Philosophical Investigations. Basil Blackwell. 